\title{
Hubungan Anti-Mullerian Hormone (AMH) pada Long dan Short Protocol Terhadap Fertilization Rate Pasien in Vitro Fertilization (IVF)
}

\author{
Rizki Amalia Wahid, Edwin Armawan, Tono Djuwantono \\ Departmen Obstetri dan Ginekologi, Fakultas Kedokteran Universitas Padjadjaran/ \\ RSUP Dr. Hasan Sadikin, Bandung \\ Korespondensi: Rizki Amalia Wahid, Email : amalia.dr08@gmail.com
}

\begin{abstract}
Abstrak
Tujuan: Untuk mengevaluasi pengaruh kadar anti-mullerian hormone (AMH) dengan fertilization rate (FR) dan menilai perbedaan pengaruh jenis protokol (long protocol (LP) dan short protocol (SP)) pada tiap tingkat cadangan ovarium terhadap FR pada pasien in vitro fertilization (IVF) dengan Intracytoplasmic Sperm Injection.

Metode: Data sekunder dari rekam medis pasien yang menjalani IVF di Aster Fertility Clinic Rumah Sakit Umum Pendidikan dr. Hasan Sadikin pada tahun 2016-2020 dan Bandung Fertility Centre Rumah Sakit Ibu Anak Limijati pada tahun 2018-2019. Penelitian ini analitik observational dengan metode Cohort retrospektif. Hubungan antara dua data kategorik diuji dengan uji chi-square dan uji Kruskal-Wallis digunakan pada data numerik dengan distribusi yang tidak rata pada lebih dari 2 kelompok,

Hasil: Hasil data diperoleh nilai rerata kadar AMH secara keseluruhan adalah $3.30 \mathrm{ng} / \mathrm{ml}$ dengan rerata capaian FR sebesar 71.97\%. Berdasarkan metode IVF yang dipilih, mayoritas pasien menjalani pengobatan SP $54.4 \%$ (rerata FR 72.80\%) dibandingkan dengan LP 45.6\% (rerata FR 70.97\%). Tidak ditemukan hubungan yang bermakna antara kadar AMH dengan FR, dinyatakan dengan nilai $\mathrm{p}=0.977$. Kadar AMH terhadap FR bila dipisahkan menurut protokol terapi yang diberikan tidak menunjukkan perbedaan yang bermakna pada masing-masing protokol (LP $\mathrm{p}=0,763 ; \mathrm{SP} \mathrm{p}=0,843)$. Mengenai hubungan antara protokol IVF dengan FR juga tidak diperoleh perbedaan yang signifikan secara statistik dengan nilai $\mathrm{p}=0,27$ (RR 1.17 (0.62-2.15); CI 95\%). Penggobatan menggunakan LP $(\mathrm{p}=0,770)$ maupun SP $(\mathrm{p}=0.845)$ tidak memberikan pengaruh yang bermakna terhadap FR pada setiap kategori AMH.
\end{abstract}

Kesimpulan: Tidak ada pengaruh kadar AMH dan protokol terapi terhadap FR.

Kata kunci : In Vitro Fertilization, Fertilization Rate, Anti-Mullerian Hormone, Protokol Stimulasi Ovarium

\section{Relation of Anti-Mullerian Hormone (AMH) in Short and Long Protocol Againts Fertilization Rate of in Vitro Fertilization (IVF) Patients}

\begin{abstract}
Objective:To evaluate the effect of anti-mullerian hormone (AMH) levels on the success of fertilization rate (FR) and assess the effect of different types of protocols (long protocol (LP) and short protocol (SP)) at each level of ovarian reserve on fertilization rate of in-vitro fertilization (IVF) patients using Intracytoplasmic Sperm Injection. Method: Secondary data from the medical records of patients undergoing IVF at the Aster Fertility Clinic, Hasan Sadikin Hospital in 2016-2020 and Bandung Fertility Center Limijati Hospital. This study was an observational analytic study with a retrospective cohort approach. The relationship between two categorical data was analyzed by chi-square and Kruskal-Wallis on numerical data that were not normally distributed in more than 2 groups.

Result: The result of obtained data is an average overall AMH level of $3.30 \mathrm{ng} / \mathrm{ml}$ with a mean FR achievement of $71.97 \%$. Based on chosen IVF method, more patient underwent short protocol $54.4 \%$ (mean FR 72.80\%) than long protocol 46.6\% (mean FR 70.97\%). There was no significant relationship between AMH levels and FR, expressed by the value of $p=0.977$. AMH levels against $F R$ when separated according to the given therapy protocol did not show any significant difference in each protocol ( $L P p=0.763$, SP $p=0.843$ ). Regarding the relationship between the IVF protocol and FR, there was also no statistically significant difference with $p$ value $=0.27$ (RR $1.17(0.62$ 2.15) $95 \% C I)$, as well as treatment using $L P(p=0,770)$ or $S P(p=0.845)$ did not have a significant effect on $F R$ at each $A M H$ category $(p=0.599)$.

Conclusion: There was no significant relationship between AMH levels and therapy protocol on FR.
\end{abstract}

Key word: In Vitro Fertilization, Fertilization Rate, Anti-Mullerian Hormone, Ovarian Stimulation Protocol 


\section{Pendahuluan}

Infertilitas didefinisikan sebagai tidak adanya kehamilan setelah 1 tahun atau 2 tahun hubungan seks tanpa kontrasepsi. ${ }^{1}$ Infertilitas dapat memberikan dampak besar tidak hanya medis, namun juga segi ekonomi dan psikologis bagi pasangan yang mengalaminya. Infertilitas terjadi pada $10-15 \%$ pasangan usia reproduksi. Tingkat infertilitas jauh dapat mencapai $30 \%$ di beberapa bagian dunia, termasuk Asia Selatan, Afrika sub-Sahara, Timur Tengah dan Afrika Utara, Eropa Tengah dan Timur serta Asia Tengah. ${ }^{2}$ Di Indonesia, persentase perempuan usia 25-49 tahun yang mengalami infertilitas primer diperkirakan $6 \%$ dari total populasi dan mencapai $21,3 \%$ pada wanita usia 20-24 tahun. ${ }^{3}$

Dalam banyak kasus, infertilitas dapat dicegah dan ditangani melalui teknik reproduksi berbantu (TRB). Fertilisasi in vitro (in vitro fertilization $=$ IVF) merupakan salah satu opsi TRB yang dilakukan dalam upaya penanganan infertilitas, setelah kegagalan teknik reproduksi berbantu lainnya. Sebuah studi di delapan pusat infertilitas di Indonesia menunjukkan tingkat keberhasilan kehamilan sebesar 29,46\%. Studi lain di Indonesia menunjukkan persentase kelahiran hidup sebesar $19,8 \%$ pada IVF. $^{4,5}$ their chances of becoming pregnant are reduced. The follicle-stimulating hormone (FSH Tujuan utama IVF adalah untuk mencapai potensi implantasi maksimum. Telah diketahui bahwa fertilization rate (FR) yang rendah menghasilkan implantation rate (IR) yang buruk dan berujung pada berkurangnya kemungkinan kehamilan. Fertilization rate merupakan perbandingan sebagai jumlah telur yang dibuahi relatif terhadap jumlah oosit yang diambil. Beberapa studi menyatakan FR dapat dijadikan prediktor yang kuat terhadap IR. ${ }^{6,7}$ Cadangan ovarium adalah salah satu konsep yang mencerminkan kualitas dan kuantitas folikel ovarium dalam memprediksipotensial ovarium terkait dengan oosit yang dihasilkan, sehinga berguna untuk memprediksi hasil IVF. ${ }^{8}$ Sebuah penelitian menunjukkan hubungan yang signifikan antara jumlah oosit dengan angka kelahiran hidup pada prosedur IVF, dikaitkan dengan 10-15 jumlah oosit yang diperoleh. ${ }^{9}$ Jumlah oosit pick-up dianggap sebagai variabel prognostik yang penting dalam keberhasilan IVF, untuk itu dibutuhkan stimulasi ovarium yang tepat untuk tiap cadangan ovarium sehingga dapat diperoleh jumlah oosit yang optimal untuk meningkatkan peluang mendapatkan lebih banyak oosit dengan kualitas yang optimal. Kadar serum AntiMullerian Hormone (AMH), dianggap sebagai penanda paling sensitif dari cadangan ovarium yang teridentifikasi hingga saat ini, oleh karena memliliki korelasi yang baik dengan jumlah oosit yang dihasilkan selama siklus stimulasi ovarium. ${ }^{10}$ AMH merupakan suatu bentuk transformasi glikoprotein dari transforming growth factor- $\beta$ (TGF- $\beta$ ) yang dihasilkan oleh sel granulosa pada folikel preantral serta folikel antral kecil dari folikel ovarium. Pelepasan AMH dari sel granulosa ovarium sebanding dengan jumlah folikel yang berkembang di ovarium, secara tidak langsung menggambarkan cadangan ovarium yang tersisa. ${ }^{11,12}$ Beberapa penelitian menyebutkan bahwa pengukuran level serum anti-AMH memungkinkan evaluasi kuantitatif dari cadangan ovarium, bukan kualitas dari oosit. ${ }^{10}$ Namun, penelitian lain menunjukkan kadar AMH serum berkorelasi dengan kualitas oosit, dimana pasien dengan kadar AMH yang rendah diduga mempunyai penurunan jumlah dan kualitas oosit lebih rendah. ${ }^{10,12-14}$ Bahkan, pada penelitian yang dilakukan pada pasien dengan PCOS yang menjalani prosedur IVF menunjukkan hubungan yang signifikan secara statistik antara kadar serum AMH terhadap FR dan IR, tidak hanya terhadap jumlah oosit dan respons ovarium. ${ }^{13-15}$ Namun demikian, apakah AMH memberikan pengaruh terhadap kualitas dari 
oosit yang sehingga berpengaruh terhadap fertilisasi yang baik masih diperdebatkan.

Berdasarkan kegunaan korelasi linear antara kadar $\mathrm{AMH}$ dan hasil oosit beberapa peneliti menyarankan agar protokol stimulasi ovarium dapat dioptimalkan sesuai dengan kadar AMH untuk meminimalkan risiko respon yang buruk dan pembatalan siklus atau hiperrespon. ${ }^{14}$ Hasil meta-analisis menunjukkan bahwa lama pemberian agonis Gonadotropin-Releasing Hormone (GnRH) dan regimen antagonis $\mathrm{GnRH}$ pada simulasi ovarium, sebanding dengan keberhasilan hasil IVF bagi responden dengan cadangan ovarian yang buruk. Namun, penggunaan regimen agonis $\mathrm{GnRH}$ dikaitkan dengan konsumsi gonadotropin yang lebih tinggi dan durasi stimulasi yang lebih lama dibandingkan dengan regimen antagonis $\mathrm{GnRH}$, sehingga regimen antagonis mungkin akan menjadi regimen yang disarankan untuk responden dengan cadangan ovarium yang buruk. ${ }^{16}$ thus maximizing the chances of pregnancy and eliminating the iatrogenic and avoidable risks resulting from ovarian stimulation. Personalization of treatment in IVF should be based on the prediction of ovarian response for every individual. The starting point is to identify if a woman is likely to have a normal, poor or a hyper response and choose the ideal treatment protocol tailored to this prediction. The objective of this review is to summarize the predictive ability of ovarian reserve markers, such as antral follicle count (AFC Penelitian mengenai perbedaan efek dari protokol terapi terhadap FR pada tiap cadangan ovarium masih kontroversial dengan kesimpulan hasil yang kontradiktif.

Beberapa pedoman disusun untuk menentukan jenis protokol dalam simulasi ovarium disesuaikan dengan kondisi pasien, namun belum tentu sesuai untuk semua populasi. Dibutuhkan suatu penelitian lebih lanjut untuk menilai efekasi dan efesiensi dari pengobatan dalam IVF sehingga pasangan bisa memilih jenis pengobatan sesuai dengan kondisi pasien. Tujuan dilakukannya penelitian ini adalah untuk mengevaluasi pengaruh kadar AMH dengan keberhasilan FR dan menilai perbedaan pengaruh jenis protokol (long protocol dan short protocol) pada tiap tingkat cadangan ovarium terhadap FR pada pasien IVF dengan Intracytoplasmic Sperm Injection (ICSI).

\section{Metode}

Penelitian ini adalah penelitian analitik observational dengan metode kohort retrospektif. Data merupakan data sekunder dari rekam medis pasien yang menjalani IVF dengan ICSI di Aster Fertility Clinic (AFC) RSUP dr. Hasan Sadikin pada tahun 2016-2020 dan Bandung Fertility Centre (BFC) RSIA Limijati pada tahun 2018-2019. Proses pengumpulan data dilakukan pada bulan Januari-Juli 2020, dengan kriteria inklusi penelitian adalah pasangan infertil dengan usia wanita 20-40 tahun. Subjek dengan riwayat endometriosis dan poli cystic ovarian syndrome (PCOS), subjek yang tidak melanjutkan program hingga tahapan fertilisasi, ataupun subjek dengan data rekam medik yang tidak lengkap, tidak diikutsertakan dalam analisis. Indikator yang digunakan untuk karakteristik pasien antara lain usia wanita, usia pria, penyebab infertilitas (primer dan sekunder) dan indikasi dilakukannya IVF (faktor sperma, faktor ovarium, faktor tuba, faktor uterus, faktor gabungan dan unexplained infertility). Fertilization rate normal ICSI didefinisikan sebagai perbandingan antara jumlah oosit yang dibuahi pada hari ke-1 (yaitu munculnya 2 pro nukleus dan 2 polar body yang dinilai pada $17 \pm 1$ jam paska injeksi) dengan jumlah kompleks oosit-kumulus. ${ }^{7} \quad$ FR sebagai variable dependent dikelompokkan menjadi 2 (dua) kelompok yaitu fertilization rate yang baik $(\geq 65 \%)$ dan fertilization rate kurang baik $(<65 \%) .{ }^{15}$ Sampel penelitian, dipisahkan menjadi 3 kategori berdasarkan kadar AMH 
sebagai prediktor ovarian reserve, yaitu kadar AMH tinggi $(>4,6 \mathrm{ng} / \mathrm{mL})$, kadar AMH normal $(1,2-4,6 \mathrm{ng} / \mathrm{mL})$ dan kadar AMH rendah $(<1,2 \mathrm{ng} / \mathrm{mL}) .{ }^{3}$ Variabel independent meliputi 2 group protokol terapi yaitu group long protocol (LP) dan short protocol (SP).

Jumlah subjek minimal pada masingmasing kategori AMH adalah 60 subjek berdasarkan perhitungan sample analisis perbedaan 2 proporsi dan pemilihan subjek menggunakan metode random sampling. Data kategorik disajikan dalam tabel distribusi frekuensi dan persentase. Sedangkan data numerik akan disajikan dalam rerata. Normalitas data diuji dengan Kolmogorov-smirnov untuk $\mathrm{N} \geq 50$ dan uji Shapiro-Wilk untuk $\mathrm{N}<50$ dengan ketentuan data dinyatakan berdistribusi normal jika $\mathrm{p}$ $>0,05$. Perbedaan rerata pada dua kelompok dilakukan dengan uji-t tidak berpasangan bila distribusi data normal dan dengan uji Mann-Whitney bila distribusi data tidak normal. Perbedaan rerata pada $>2$ kelompok dilakukan dengan uji ANOVA bila distribusi data normal dan uji Kruskal-Wallis bila distribusi data tidak normal. Hubungan antara dua data kategorik akan diuji dengan uji chisquare. Kemaknaan hasil uji dinferensial diletakkan berdasarkan nilai $\mathrm{p}<0,05$. Data yang diperoleh dicatat dalam formulir khusus kemudian diolah melalui program IBM SPSS (International Business Machines: Statistical Packages for the Social Sciences) versi 22.0 untuk Windows.

\section{Hasil}

Hasil pengumpulan data rekam medis dari pasangan infertil yang melakukan prosedur IVF di AFC RSUP Dr. Hasan Sadikin dan BFC RSIA Limijati, kota Bandung pada periode waktu yang telah ditentukan, jumlah subjek penelitian yang berhasil terkumpul dan memenuhi syarat inklusi adalah sebanyak 341 pasangan. Berdasarkan perhitungan jumlah sample dengan uji hipotesis 2 porposi, maka total subjek yang diteliti adalah 195 subjek dengan porposi 65 subjek pada tiap kategori kadar AMH yang diperoleh secara random sampling. Hasil data diperoleh rerata usia wanita berkisar 33,72 tahun sedangkan rerata usia pria 37.14 tahun. Nilai rerata capaian fertilisasi secara keseluruhan sample sebesar $71.97 \%$ dengan kadar rerata AMH pasien pada cadangan ovarium yang rendah sebesar $0.74 \mathrm{ng} / \mathrm{ml}$ (rerata FR 72.78\%), normal sebesar $2.60 \mathrm{ng} / \mathrm{ml}$ (rerata FR 71.23\%) dan tinggi sebesar $6.55 \mathrm{ng} / \mathrm{ml}$ (rerata FR 71.92\%). Berdasarkan metode IVF yang dipilih, mayoritas pasien menjalani pengobatan SP, yaitu $54.4 \%$ (rerata FR $72.80 \%$ ) dibandingkan dengan LP sejumlah 45.6\% (rerata FR 70.97\%). Karakteristik sampel dapat disimak di tabel 1. Kadar AMH secara keseluruhan adalah $3.30 \mathrm{ng} / \mathrm{ml}$. Dilihat hubungannya terhadap semua variabel, terlihat bahwa tidak ada perbedaan bermakna antara kadar AMH berdasarkan karakteristik jenis infertilitas, indikasi IVF. Hal ini terlihat dari nilai-p yang dihasilkan dari analisis bivariat lebih dari 0,05 yang menunjukkan tidak ada perbedaan AMH yang bermakna pada seluruh subjek penelitian berdasarkan variabel-variabel tersebut. Hal ini menunjukkan profil yang serupa pada sisi demografik subjek.

Sedangkan pemberian protokol mempunyai nilai $\mathrm{P}<0.05$ menunjukkan adanya perbedaan bermakna pada perlakuan, sehingga protokol terapi merupakan confounding factor yang perlu dipertimbangkan.

Pada tabel 2 stimulasi ovarium dengan LP, menunjukkan angka keberhasilan FR yang tinggi pada tiap kadar $\mathrm{AMH}$, dengan perbandingan tingkat keberhasilan FR paling tinggi ditemukan pada kadar AMH tinggi (>4.6). Namun demikian, tidak ditemukan hubungan yang bermakna antara Kadar AMH dengan tingkat keberhasilan FR dengan LP. Hubungan kadar AMH pada seluruh kategori AMH dinyatakan tidak bermakna dengan nilai $\mathrm{p}=0,977$. 


\section{Tabel 1 Karakteristik Sampel}

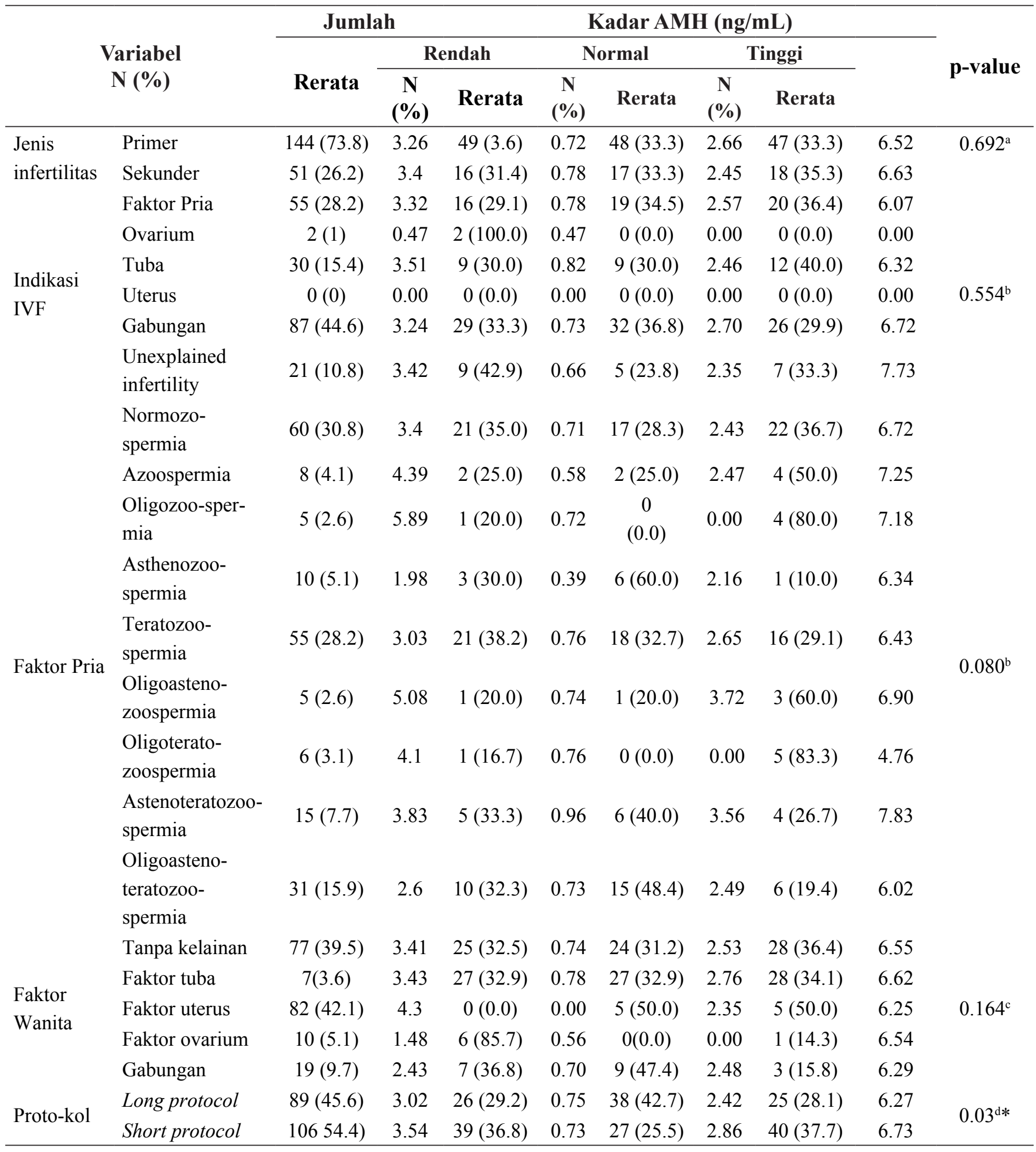

a) Uji Mann-Whitney b) Uji Chi-square c) Uji Kruskal-Wallis d) Uji Chi-square *) P dianggap bermakna $<0.05$ 
Begitupun hubungan antara kadar AMH dengan FR pada stimulasi ovarium dengan SP, dinyatakan tidak bermakna dengan nilai $\mathrm{p}=0,843$. Angka keberhasilan FR yang tinggi juga mendominasi tiap kadar $\mathrm{AMH}$, dengan perbandingan tingkat keberhasilan FR paling tinggi ditemukan pada kadar AMH normal $(1.2$ - 4.6). Hal yang serupa ditemukan pada analisis hubungan kadar AMH terhadap FR tanpa mengindahkan protokol terapi yang diberikan, menunjukkan perbedaan yang tidak bermakna pada masing-masing kadar AMH dengan nilai $\mathrm{p}=0.977$.

Pada tabel 4 uji Kruskal-Wallis digunakan untuk menilai pengaruh Protokol IVF terhadap rerata FR pada masing-masing tingkat AMH. Hasil analisis menyimpukan bahwa tidak ada perbedaan median FR yang bermakna baik pada kelompok AMH rendah, normal maupun tinggi. Dalam arti kata LP tidak memberikan perbedaan pengaruh yang signifikan secara statistik terhadap hasil FR pada masing-masing kadar AMH, begitupun SP. Analisis juga dilakukan untuk menilai perbedaan pengaruh LP dan SP terhadap FR secara keseluruhan, namun tetap tidak memberikan pengaruh yang signifikan secara statistik $(\mathrm{p}=0.27)$. Relative risk pada kelompok SP untuk mendapatkan nilai FR diatas 65 persen adalah 1.17 dibandingkan LP, hal tersebut menunjukkan SP lebih baik. Tapi bila dilakukan penelitian tidak hingga, akan didapatkan RR 0.643 - 2.152 yang artinya short protokol tidak konsisten lebih baik dibandingkan long protokol.

\section{Pembahasan}

Tujuan utama IVF adalah untuk mencapai kelahiran hidup cukup bulan. Namun, karena jumlah oosit yang diambil dianggap sebagai variabel prognostik yang penting, protokol pengobatan IVF ditujukan untuk mengoptimalkan hasil ini. Studi yang mengevaluasi rejimen pengobatan IVF dan tes cadangan ovarium seperti hormon antimu llerian sering menggunakan jumlah oosit sebagai outcome pengganti, namun, hal tersebuttelahbanyak dikritik karena hubungan antara jumlah oosit dan kelahiran hidup masih kurang dipahami. ${ }^{9}$ Walaupun, terdapat banyak sekali perdebatan yang mendukung kadar AMH sebagai perdiktor cadangan ovarium dan kemampuan prediktifnya dalam keberhasilan IVF, Konsensus Infertilitas di Indonesia masih merekomendasikan pemilihan protokol stimulasi ovarium dan menentukan dosis gonadotropin dapat dipertimbangkan berdasarkan hasil penilaian cadangan ovarium untuk menggambarkan tingkat potensial fungsi reproduksi terutama dalam kuantitas dan kualitas oosit dengan AMH dan AFC sebagai prediktor, serta faktor predisposisi lainnya. (Rekomendasi A). ${ }^{3}$

Hormon antimullerian (AMH), juga dikenal sebagai zat penghambat mullerian (MIS), adalah anggota glikoprotein dimer dari keluarga faktor pertumbuhan- $\beta$ transformasi. Sekresinya menurun saat folikel antral mulai tumbuh, dan berhenti saat diameter folikel lebih besar $8 \mathrm{~mm}$, atau saat atresia terjadi. AMH hampir tidak terdeteksi pada bayi perempuan yang baru lahir dan puncaknya setelah pubertas dan terus menurun sampai menopause ketika konsentrasi serum menjadi tidak terdeteksi. Peran AMH dalam ovarium adalah berperan serta dalam pengaturan fungsi ovarium, terutama dalam perkembangan dan seleksi folikel. AMH menghambat inisiasi pertumbuhan folikel primordial manusia dan mencegah beberapa seleksi dari folikel dominan dengan mengurangi sensitivitas folikel terhadap hormon perangsang folikel (FSH). ${ }^{12}$

Beberapa laporan sebelumnya telah menunjukkan nilai $\mathrm{AMH}$ dalam memprediksi kualitas oosit, kualitas embrio, FR dan PR. Tingkat AMH yang rendah dapat dikaitkan dengan kualitas oosit yang buruk sehingga FR berkurang. ${ }^{13,14}$ Studi lain telah mengindikasikan bahwa oosit 
Tabel 2 Pengaruh AMH terhadap FR pada Long Protocol

\begin{tabular}{|c|c|c|c|c|c|c|}
\hline & & & \multicolumn{2}{|c|}{ FR } & \multirow{2}{*}{$X_{2}$} & \multirow{2}{*}{$p$-value ${ }^{a}$} \\
\hline & & & $<65 \%(\mathrm{n}(\%))$ & $<65 \%(\mathrm{n}(\%))$ & & \\
\hline \multirow{3}{*}{ LP } & \multirow{3}{*}{$\begin{array}{l}\text { Kadar AMH } \\
(\mathrm{ng} / \mathrm{ml})\end{array}$} & $<1.2$ & $9(34.62 \%)$ & $17(65.38 \%)$ & \multirow{3}{*}{0,541} & \multirow{3}{*}{0.763} \\
\hline & & $1.2-4.6$ & $14(36.84 \%)$ & $24(63.16 \%)$ & & \\
\hline & & $>4.6$ & $7(28.00 \%)$ & $18(72.00 \%)$ & & \\
\hline
\end{tabular}

a) Uji Chi-Square

Tabel 3. Pengaruh AMH terhadap FR pada Short Protocol

\begin{tabular}{|c|c|c|c|c|c|c|}
\hline & & & \multicolumn{2}{|c|}{ FR } & \multirow[t]{2}{*}{$\mathrm{X} 2$} & \multirow[t]{2}{*}{$p$-value $e^{a)}$} \\
\hline & & & $<65 \%(\mathrm{n}(\%))$ & $\geq 65 \%(n(\%))$ & & \\
\hline \multirow{3}{*}{ SP } & \multirow{3}{*}{$\begin{array}{l}\text { Kadar AMH } \\
(\mathrm{ng} / \mathrm{mL})\end{array}$} & $<1.2$ & $12(30.77 \%)$ & $27(69.23 \%)$ & \multirow{3}{*}{0,340} & \multirow{3}{*}{0.843} \\
\hline & & $1.2-4.6$ & $7(25.93 \%)$ & $20(74.07 \%)$ & & \\
\hline & & $>4.6$ & $13(32.50 \%)$ & $27(67.50 \%)$ & & \\
\hline
\end{tabular}

a) Uji Chi-Square

Tabel 4. Pengaruh Protokol terapi terhadap FR

\begin{tabular}{|c|c|c|c|c|c|}
\hline \multirow{2}{*}{\multicolumn{2}{|c|}{$\mathrm{AMH}<1.2$}} & \multicolumn{3}{|c|}{ Median FR } & \multirow[b]{2}{*}{$p$-value $e^{a)}$} \\
\hline & & $\begin{array}{c}\text { AMH } \\
1.2-4.6\end{array}$ & $\mathrm{AMH}>4.6$ & & \\
\hline Protokol & LP & 71.4 & 70.7 & 70.9 & 0.770 \\
\hline terapi & $\mathrm{SP}$ & 73.6 & 71.9 & 72.5 & 0.845 \\
\hline
\end{tabular}

a) Uji Kruskal-Wallis

lebih mungkin untuk dibuahi ketika folikel mereka menghasilkan tingkat AMH yang tinggi, karena kadar AMH cairan folikel lebih dari tiga kali lebih tinggi pada folikel dengan oosit yang dibuahi, dibandingkan pada mereka yang tidak memiliki oosit yang dibuahi. Lin WQ dengan studinya mengemukakan tidak ada hubungan yang signifikan antara serum AMH basal dengan Gonadotropin 6 AMH (Gn6AMH) atau folikel fluid (FF) AMH dan FR selama IFV/ ICSI. ${ }^{12}$ Berdasarkan Pustaka diatas, diperoleh perbedaan pendapat mengenai pengaruh AMH terhadap FR, namun kami mengambil hipotesa bahwa nilai AMH tidak mempunyai pengaruh yang bermakna terhadap FR, karena AMH merupakan prediktor cadangan ovarian dalam hal kuantitas bukan kualitas. Pada penelitian kami, tidak ditemukan hubungan yang bermakna antara Kadar AMH dengan FR. Hubungan kadar AMH pada seluruh kategori dinyatakan tidak bermakna dengan nilai $p=0,977$. Begitupun hubungan kadar AMH terhadap FR bila dipisahkan menurut protokol terapi yang diberikan, tidak menunjukkan perbedaan yang bermakna pada masing-masing protokol. Kami tidak dapat mengamati peningkatan signifikan dalam kemungkinan kehamilan melalui FR sebagai parameter pengganti, seiring dengan peningkatan AMH serum. Secara bersamasama, temuan ini mendukung gagasan bahwa AMH dapat menjadi indeks kuantitatif respon ovarium, tetapi bukan penanda kompetensi oosit yang dapat diandalkan untuk kehamilan. Sependapat dengan hasil penelitian lain yang menunjukkan tidak ada hubungan bermakna antara AMH dengan FR. ${ }^{8,14,16,17}$

Beberapa penelitian sebelumnya telah menunjukkan bahwa baik AMH serum dasar 
tidak dikaitkan dengan kualitas oosit dan FR. Telah diusulkan bahwa tingkat AMH yang berbeda dapat memprediksi kualitas oosit, tetapi bukan kemampuannya untuk dibuahi. ${ }^{12}$ Proses fertilisasi dimulai dengan fusi gamet dan mencakup peristiwa lainnya yang terkait dengan aktivasi telur sampai saat telur berkomitmen untuk perkembangan embrio. Hasil pengamatan menunjukkan bahwa tingkat AMH berpengaruh negatif terhadap pembuahan dan kualitas oosit, kemungkinan karena hubungan antara metabolisme sel granulosa dan kompetensi perkembangan oosit. Tingkat apoptosis sel mural dan kumulus granulosa berpengaruh negatif terhadap kompetensi perkembangan oosit. Dengan demikian atresia folikel mencegah ekspresi AMH. ${ }^{14}$ Sejalan dengan penelitian tersebut, studi lain mendukung bahwa tidak ada hubungan yang signifikan antara $\mathrm{AMH}$ serum basal, Gn6AMH atau FF AMH dan FF selama IVF dengan ICSI. Sebuah studi pada pasien non-obesitas dengan sindrom ovarium polikistik non-hiperandrogenemik menyatakan tidak ada korelasi antara FF AMH dan proporsi oosit dalam metafase II. Penelitian lain mengkaji antara hubungan AMH dengan kualitas embrio, pertumbuhan blastosit dan PR, menunjukkan hasil bahwa konsentrasi FF AMH tidak mencerminkan tingkat $\mathrm{AMH}$ dalam folikel individu. Ini mungkin menjelaskan mengapa tidak dapat menemukan hubungan antara FF AMH dan tingkat pembuahan. ${ }^{12}$ Hasil penelitian kami mendukung hipotesis bahwa AMH tidak memberikan pengaruh bermakna terhadap FR, walaupun jumlah oosit sedikit namun memiliki kualitas yang baik akan memberikan angka FR yang tinggi, beruujung pada angka kelahiran hidup yang tinggi. Untuk meningkatkan prediksi kehamilan dan kelahiran hidup, metode untuk menafsirkan kadar AMH sebagai penanda kualitatif dari fungsi ovarium, harus lebih dieksplorasi, dengan demikian kadar AMH tidak mutlak dijadikan acuan dalam pemilihan protokol stimulasi ovarium.

Tujuan utama individualisasi pengobatan dalam IVF adalah untuk menawarkan kepada setiap wanita perawatan terbaik yang disesuaikan dengan karakteristik uniknya, sehingga memaksimalkan kemungkinan kehamilan dan menghilangkan risiko iatrogenik dan yang dapat dihindari akibat stimulasi ovarium. Personalisasi pengobatan pada IVF harus didasarkan pada prediksi respon ovarium untuk setiap individu. Tidak ada konsensus tentang protokol mana yang merupakan pengobatan terbaik untuk semua pasien, karena banyak penelitian tidak menunjukkan perbedaan yang signifikan antara kedua protokol tersebut. ${ }^{17}$ (a Dua meta-analisis menunjukkan hasil yang berbeda, data dalam satu meta-analisis melaporkan bahwa LP lebih efektif daripada SP dalam hal pengambilan oosit dan tingkat kehamilan klinis. Namun, metaanalisis lainnya menyimpulkan bahwa tidak ada perbedaan antara kedua protokol. ${ }^{18}$ Nelson et al. menyimpulkan dalam studi kohort prospektif mereka yang besar bahwa pengukuran tunggal AMH dapat digunakan untuk mengkategorikan pasien dan memiliki pengaruh pada beban pengobatan dan hasil klinis. Mereka juga menyatakan bahwa protokol antagonis memiliki hasil yang lebih baik pada cadangan ovarium yang ekstrem. ${ }^{19}$

Pada studi ini, kami berhipotesa bahwa tidak ada perbedaan yang bermakna antara stimulasi ovarium dengan LP dibadingkan dengan SP pada tiap kategori cadangan ovarium berdasarkan tingkat AMH terhadap FR. Penelitian kami mendukung hipotesa tersebut. Hasil penelitian menunjukkan bahwa tidak ada perbedaan pengaruh yang bermakna stimulasi ovarium dengan LP dan SP terhadap FR pada semua kategori AMH. Stimulasi ovarium LP pada kadar AMH rendah tidak lebih efektif dibandingkan kategori AMH lainnya $(p=0.770)$, hal yang sama juga ditemukan pada stimulasi menggunakan SP $\quad(p=0.845)$ Dapat 
disimpulkan bahwa, prediktif keberhasilan IVF melalui parameter FR dengan metode stimulasi ovarium apapun, mungkin tercapai meskipun tingkat $\mathrm{AMH}$ serum sangat rendah ataupun sebaliknya. Hasil penelitian kami sejalan dengan pedoman stimulasi ovarium yang di publikasikan European Society of Human Reproduction and Embryology (ESHRE). Protokol antagonis GnRH direkomendasikan untuk responden dengan cadangan ovarium yang tinggi (dihubungkan dengan tingkat keamanan) namun memiliki kemanjuran yang setara dengan protokol agonis. Jika protokol agonis GnRH digunakan, maka direkomendasikan untuk mengurangi dosis gonadotropin, dengan tujuan meminimalisasikan risiko ovarian hyperstimutation syndrome (OHSS). Protokol antagonis GnRH direkomendasikan untuk responden yang diprediksi memiliki cadangan ovarian normal, juga sematamata untuk tingkat keamanan. Begitupun dengan responden yang diprediksi memiliki cadangan ovarium yang rendah, ptotokol antagonis GnRH dan agonis GnRH samasama direkomendasikan. ${ }^{20}$

Dari sudut pandang klinis, temuan terpenting dari penelitian ini adalah bahwa pasien dengan tingkat $\mathrm{AMH}$ kategori rendah masih memiliki peluang yang wajar untuk hamil dengan IVF baik menggunakan stimulasi ovarium dengan SP maupun LP dan mereka harus diyakinkan tentang prognosis reproduksinya. Sesuai dengan nilai-p sebesar 0,599 $(\mathrm{P}>0,05)$ yang berarti tidak adanya pengaruh yang bermakna antara protokol terapi SP dan juga LP pada masing-masing kadar AMH._ Dengan kata lain, penggunaan LP tidak memberikan efek lebih baik daripada SP pada pasien dengan cadangan ovarium yang rendah. Mengingat, efek samping utama dari LP (agonis GnRH) termasuk durasi pengobatan yang lebih lama, lebih banyak ampul digunakan, pembentukan kista ovarium dan sindrom menopause (misalnya, hot flushes, kekeringan vagina dll), protokol antagonis (SP) dapat mengatasi efek samping ini. Namun, kerugiannya dari SP adalah produksi folikel yang rendah. Lebih lanjut, protokol antagonis memiliki tingkat kehamilan dan implantasi yang lebih rendah karena tingkat LH yang rendah dan gangguan sekresi estrogen. Bila dibandingkan dengan pasien yang diobati dengan protokol antagonis, pasien yang diobati dengan protokol agonis menunjukkan jumlah oosit yang diambil dan produksi oosit matang secara signifikan lebih tinggi. ${ }^{21}$ Namun demikian, mengingat prediksi kehamilan tidak mutlak dipengaruhi oleh kuantitas oosit, maka pasien tanpa morbiditas dapat memilih protokol terapi yang sesuai dengan kondisi pasien karena kedua efek protokol terapi pada tiap cadangan ovarium yang berbeda memiliki efekasi yang sama terhadap FR.

Ketersediaan penanda baru cadangan ovarium, peningkatan metodologi untuk pengukurannya dan sejumlah besar data klinis telah mendukung pandangan bahwa individualisasi dalam IVF bukanlah hal baru dalam bidang kedokteran. Respon ovarium dalam IVF adalah hal kompleks yang sekarang kita ketahui sebagai bagian terpenting. Definisi yang jelas untuk modalitas penerapan yang benar berdasarkan respon ovarium dari terapi individual masih diperlukan untuk mengoptimalkan kemanjuran dan manajemen klinis harian sehingga dapat menghindari pengurangan insiden risiko pengobatan dan penghentian pengobatan serta berkurangnya beban pengobatan. ${ }^{17}$

Penelitian ini terbatas dari jumlah populasi yang tersedia, untuk itu diperlukan suatupenelitianlanjutandenganmenggunakan jumlah subjek penelitian yang lebih besar. Selain itu angka FR pada masing-masing centre penelitian diperoleh dari penilaian beberapa orang analis, sebaiknya dilakukan pengujian koefisien Cohen's Kappa pada tiap analis untuk mengurangi bias penilaian. Namun demikian, data penelitian diperoleh dari centre ternama di Indonesia dimana salah 
satu centre berafiliasi dengan rumah sakit pendidikan dan merupakan pusat rujukan di Indonesia. Penelitian ini merupakan salah satu dari sedikit penelitian yang dilakukan di Indonesia, dengan profil yang serupa pada sisi demografik pasien, sehingga hasil penelitian ini dapat menambahkan informasi yang bisa diteliti oleh para peneliti lain pada beragam karakter populasi lainnya.

\section{Conflict of Interest}

Penulis tidak memiliki afiliasi dan tidak menerima sponsor dari organisasi manapun. Semua hasil penelitian yang dicantumkan sesuai dengan pengamatan penulis saat pengambilan data dan tidak dipengaruhi oleh pengaruh luar.

\section{Daftar Pustaka}

1. Berek JS. Berek \& Novak's Gynecology. Barek \& Novac's Gynecology. 2020. 911-967 p.

2. Inhorn MC, Patrizio P. Infertility around the globe: New thinking on gender, reproductive technologies and global movements in the 21 st century. Hum Reprod Update. 2014;21(4):411-26.

3. HIFERI, PERFITRI, IAUI, POGI. Konsensus Penanganan Infertilitas. Jakarta: HIFERI, PERFITRI, IAUI, POGI; 2019.

4. Buchori M, Patria SY, Wibowo T, Hanoum IF. Neonatal outcomes in in vitro fertilization (IVF) pregnancies. J thee Med Sci (Berkala Ilmu Kedokteran). 2018;50(2).

5. Iffanolida PA, Wiweko B, Muna N, Hanifah N, Mutia K, Riayati O, et al. Gene expression of follicle-stimulating hormone receptors in granulosa cells in poor ovarian responders. J Phys Conf Ser. 2018;1073(3).

6. Jawed S, Rehman R, Ali MA, Abdullah $\mathrm{UH}$, Gul H. Fertilization rate and its determinants in intracytoplasmic sperm injection. Pakistan J Med Sci. 2016;32(1):3-7.

7. Rosen MP, Shen S, Rinaudo PF, Huddleston HG, McCulloch CE, Cedars MI. Fertilization rate is an independent predictor of implantation rate. Fertil Steril [Internet]. 2010;94(4):132833. Available from: http://dx.doi. org/10.1016/j.fertnstert.2009.05.024

8. Iwase A, Nakamura T, Osuka S, Takikawa S, Goto M, Kikkawa F. Anti-Müllerian hormone as a marker of ovarian reserve: What have we learned, and what should we know? Reprod Med Biol. 2016;15(3):127-36.

9. Sunkara SK, Rittenberg V, RaineFenning N, Bhattacharya S, Zamora J, Coomarasamy A. Association between the number of eggs and live birth in IVF treatment: An analysis of 400 135 treatment cycles. Hum Reprod. 2011;26(7):1768-74.

10. Takahashi C, Fujito A, Kazuka M, Sugiyama R, Ito $\mathrm{H}$, Isaka $\mathrm{K}$. AntiMüllerian hormone substance from follicular fluid is positively associated with success in oocyte fertilization during in vitro fertilization. Fertil Steril. 2008;89(3):586-91.

11. Permana R, Widad S, Lutfi M. Hubungan kadar anti mullerian hormone (amh) dengan keberhasilan stimulasi ovarium pada fertilisasi in vitro metode protokol panjang. J Kesehat Reproduksi; Vol 2, No 3 [Internet]. 2016; Available from: https:// jurnal.ugm.ac.id/jkr/article/view/12649

12. Lin WQ, Yao LN, Zhang DX, Zhang $\mathrm{W}$, Yang XJ, Yu R. The predictive value of anti-mullerian hormone on embryo quality, blastocyst development, and pregnancy rate following in vitro fertilization-embryo transfer (IVF-ET). J Assist Reprod Genet. 2013;30(5):64955.

13. Borges E, Braga DPAF, Setti A, Figueira 
$\mathrm{R}$ de $\mathrm{C}$, Iaconelli $\mathrm{A}$. The predictive value of serum concentrations of anti-Müllerian hormone for oocyte quality, fertilization, and implantation. J Bras Reprod Assist. 2017;21(3):176-82.

14. Kaya C, Pabuccu R, Satroglu H. Serum antimüllerian hormone concentrations on day 3 of the in vitro fertilization stimulation cycle are predictive of the fertilization, implantation, and pregnancy in polycystic ovary syndrome patients undergoing assisted reproduction. Fertil Steril [Internet]. 2010;94(6):22027. Available from: http://dx.doi. org/10.1016/j.fertnstert.2009.12.002

15. The Vienna consensus: report of an expert meeting on the development of art laboratory performance indicators $\uparrow \ddagger$. Hum Reprod Open. 2017;2017(2):1-17.

16. LaMarcaA, SunkaraSK. Individualization of controlled ovarian stimulation in IVF using ovarian reserve markers: From theory to practice. Hum Reprod Update. 2014;20(1):124-40.

17. La Marca A, Ferraretti AP, Palermo R, Ubaldi FM. The use of ovarian reserve markers in IVF clinical practice: A national consensus. Gynecol Endocrinol. 2016;32(1):1-5.

18. Ou J, Xing W, Li Y, Xu Y, Zhou C. Short versus Long GonadotropinReleasing hormone analogue suppression protocols in IVF/ICSI cycles in patients of various age ranges. PLoS One [Internet]. 2015;10(7):1-11. Available from: http://dx.doi.org/10.1371/journal. pone. 0133887

19. Nelson SM, Yates RW, Lyall H, Jamieson M, Traynor I, Gaudoin M, et al. AntiMüllerian hormone-based approach to controlled ovarian stimulation for assisted conception. Hum Reprod [Internet]. 2009 Apr 1;24(4):867-75. Available from: https://doi.org/10.1093/humrep/den480

20. Ovarian Stimulation TEGG on, Bosch E, Broer S, Griesinger G, Grynberg M,
Humaidan $\mathrm{P}$, et al. ESHRE guideline: ovarian stimulation for IVF/ICSI $\uparrow$. Hum Reprod Open. 2020;2020(2):1-13.

21. Shrestha D, La X, Feng HL. Comparison of different stimulation protocols used in in vitro fertilization: A review. Ann Transl Med. 2015;3(10):1-7. 